\title{
INFLUENCE OF MAGNETO-ABRASIVE MACHINING DURATION ON THE PRECISION OF HSS TAPS
}

\author{
Victor Maiboroda'; Dmytro Tarhan ${ }^{1}$; Oleksiy Byelyayev²; Dmytro Dzhulii ${ }^{1}$ \\ ${ }^{1}$ National Technical University of Ukraine «Igor Sikorsky Kyiv Polytechnic \\ Institute», Kyiv, Ukraine \\ ${ }^{2}$ «ZOM Oberflächenbearbeitung GmbH», Magdeburg, Germany
}

\begin{abstract}
Summary. The article presents the results of a research of the influence of magneto-abrasive machining duration on the precision of HSS taps with various diameters. Magneto-abrasive machining of taps under correctly selected conditions does not leads to a critical change in diameters, which during operation can lead to discarded parts. The reduction of diameter occurs in the first 3-6 minutes of machining. The reason for this is the removal of burrs from the tops of the teeth, grinding defects and rounding of the cutting edges of the tool. The reduction of diameter is cyclically repeated. This is due to the cyclic change in the physical and mechanical properties of thin surface layers of the material of tool and their periodic removal.
\end{abstract}

Key words: tap, precision, magneto-abrasive machining.

Statement of the problem. Modern production uses the advanced technology, systems with numerical control. It is characterized by high efficiency and productivity of metal machining, therefore it requires a reliability, high-quality and precision cutting tools. To obtain internal threads in mechanical engineering, various methods are used, such as cutting with a cutter and taps, milling, knurling on machine. Cutting with taps in modern production is the main type of technological operations in the manufacture of internal threads, especially in holes of small and medium diameters [1]. The quality of the tool substantially depends on the shape of the cutting edges, roughness and physical and mechanical characteristics of the surface layers of its working elements, which in most cases are formed at the finish stages of manufacturing using new, integrated technologies in tool production. It is important that after the finish stages of tool manufacturing the geometry and precision of the working parts do not change, but take the necessary shape and characteristics. Otherwise, there is a high probability of discarded parts during their production, which will lead to significant financial losses.

Magneto-abrasive machining (MAM) is one of the promising finish manufacturing operations in the production of high quality taps. This method allows carrying out the complex influence on the state of the surface layer, controlled change its physical and mechanical properties, microgeometry of the working surfaces and cutting edges of the cutting tools [2-8].

Analysis of the available investigations. One of the first, who began researching the process of magneto-abrasive machining of cutting tools, was Baron Yu. M. In his work [8] are described the main process parameters, that influence on the size precision and shape of the machined surface. These include fraction and composition of magneto-abrasive powder (MAP), material of the workpiece and the shape of its surfaces, the magnitude of the magnetic field in the working area and its type, the speed of relative moving of particles and the surfaces ant time of machining. The average value of the removed allowance was $4 \mu \mathrm{m}$ [8] for $30 \mathrm{~s}$ of polishing of ground rollers made of U8A (AISI W108) steel on the setup with small gaps in the working area. The author notes that for parts with complex shape determine the productivity of 
manganito-abrasive machining, that is the amount of material removal per time unit, is possible only by an experimental method.

The results of the research of the productivity of the magneto-abrasive machining as the dependence of the dimensional removal of material on the machining time are presented in the works $[9,10]$. Wherein the machining time is a key factor. The intensity of the MAM process was studied on the outer diameter of the gear in [9]. Was determined, that the main removal of material from the surface of the gear wheel occurs in the first 2-4 minutes, when there is an active removal of microroughnesses. Further, the process of material removal is reduced. The outer diameter of the gear wheel reduces by $40 \mu \mathrm{m}$ in 8 minutes of active machining.

Studies of the effect of MAM on the size changing of high speed steel drills along the length of the working part showed, that a decrease in the diameter of the drill from the machining time is $(1-5) \cdot 10^{-7} \mathrm{~mm} / \mathrm{s}$ and it is almost identical along the all length of the tool [2, 11]. The change in diameter after 10 min of machining in various sections along the axis does not exceed $10 \mu \mathrm{m}$.

The question of influence of the MAM on the precision of taps was partially considered in works [8, 12 and 13]. However, the results of their researches are based on the mass fraction of the removed material and aimed more at achieving specific characteristics of the working surfaces. The results of these studies do not allow to evaluate the influence of the process on the geometric precision of the working part of the tap and to select the machining time, which will ensure the preservation the working capacity of tool.

The Objective of the work was researching of the effect of magneto-abrasive machining duration on the precision of HSS taps and determining the time, which is advisable for machining.

Statement of the task. To perform magneto-abrasive machining of taps of various diameters with different machining times. To measure the change in tool diameter after machining and make conclusions about the effect of the MAM process duration on the precision of the HSS-taps.

Conditions of experimental research. The researches were carried out on HSS taps of three different diameters: M12x1.75-6H Walter Prototyp PARADUR, M10x1-6H Walter Prototyp PARADUR, M6x0.75-6H Narex (Figure 1).

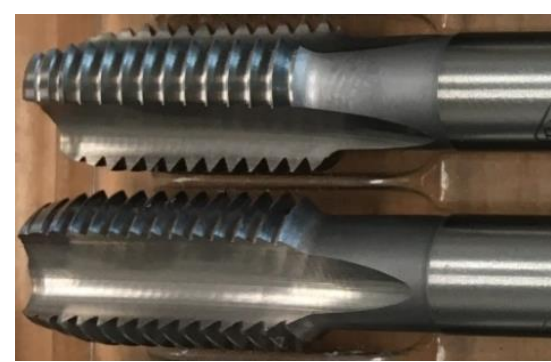

M12x1.75-6H Walter Prototyp PARADUR

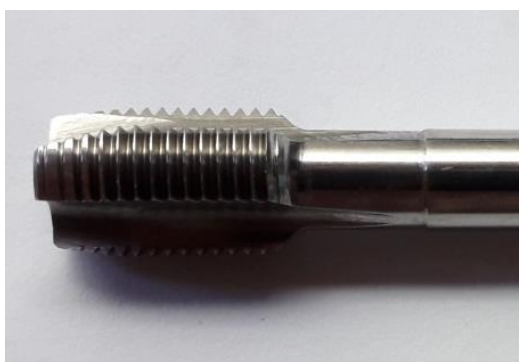

M10x1-6H Walter Prototyp PARADUR

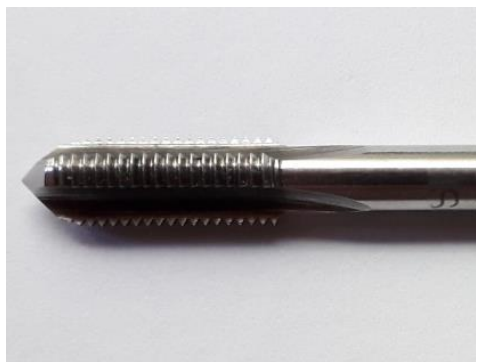

M6x0.75-6H Narex

Figure 1. Appearance of taps

Magneto-abrasive machining was performed on an experimental machine [2], which provides the ability to rotate parts with reverse around the axis of the working area and around its own axis with adjustable speed. This machine provides also the possibility of variable angular location of parts relative to the plane of the working area $-p$ and relative to the tangent to the circle of rotation around the axis of the working area $-q$. The angles of taps location in the working area of the machine and the machining conditions were selected according to the results of calculations in [14] and recommendations in [2]. MAM of taps were carried out using 
a Polymam-T magneto-abrasive powder, which showed an effective result of machining the tools from high-speed steel [2, 3, 6, 8, and 11]. The nonmagnetic rod element with a diameter of $8 \mathrm{~mm}$ was used to restore the shape of a magneto-abrasive tool during machining. «АСФОЛ» was used as a cutting fluid.

The external diameter of the taps was measured before and after MAM. The measurements were carried out on the setup for dimensional adjustment and measurement of cutting tools Venturion 450/6 («ZOM Oberflächenbearbeitung GmbH», Magdeburg, Germany). The setup is equipped with a high-precision spindle, which allows to measure diameter with an accuracy of $0.002 \mathrm{~mm}$. The appearance of the setup is shown in Figure 2.
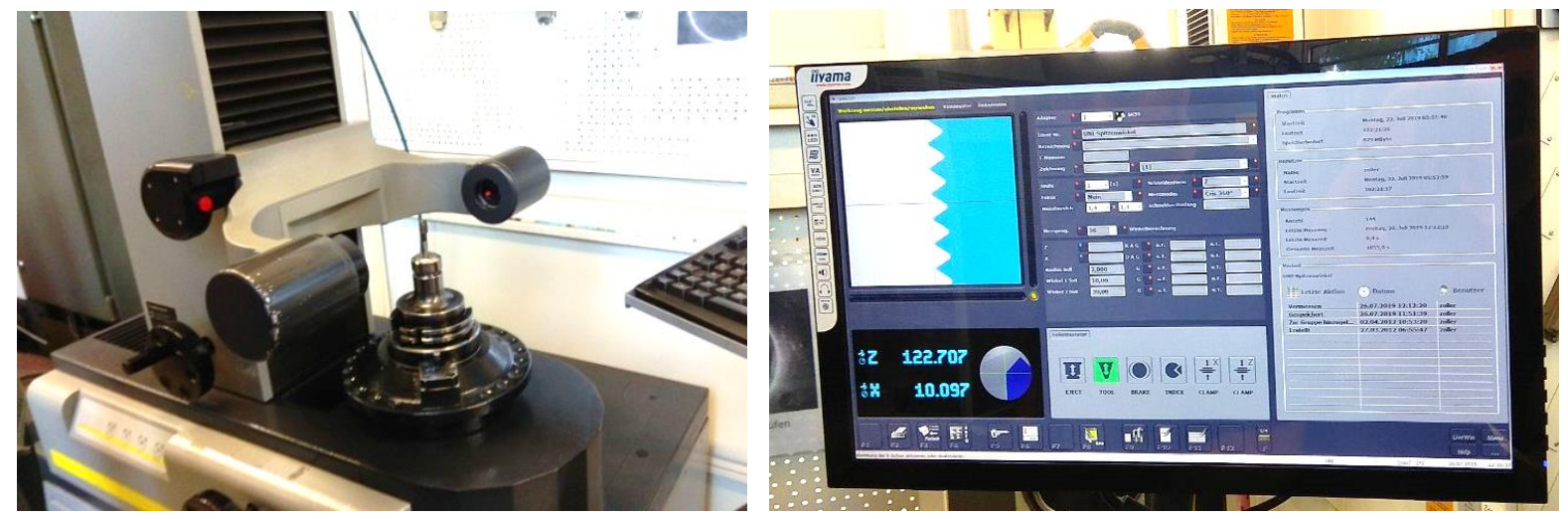

Figure 2. Setup for dimensional adjustment and measurement of cutting tools Venturion 450/6

Research results. Machining conditions of M12 taps: speed of movement along the ring-type working area of the machine $-\mathrm{V}_{\mathrm{B}}=2.5 \mathrm{~m} / \mathrm{s}$, the rotational speed around its own axis $-\mathrm{V}_{\mathrm{O}}=700 \mathrm{rpm}$, value of the magnetic induction in the working area $\mathrm{B}=0.25 \mathrm{~T}$, angle $\mathrm{p}=70^{\circ}$. The results of measuring the outer diameter of the M12 taps are presented in Table 1 .

Table 1

The results of measuring the outer diameter of the M12 taps

\begin{tabular}{|c|c|c|c|c|c|c|c|}
\hline \multirow[b]{2}{*}{ № } & \multirow{2}{*}{$\begin{array}{c}\text { Tap } \\
\text { accuracy }\end{array}$} & \multirow{2}{*}{$\begin{array}{c}\text { Total } \\
\text { machining } \\
\text { time, min }\end{array}$} & \multicolumn{5}{|c|}{ Outer diameter $d, \mathrm{~mm}$} \\
\hline & & & $\begin{array}{c}\text { GOST } \\
16925-93\end{array}$ & $\begin{array}{l}\text { Before } \\
\text { MAM }\end{array}$ & $\begin{array}{l}\text { After } \\
\text { MAM }\end{array}$ & $\Delta d, \mathrm{~mm}$ & MAP \\
\hline 1 & \multirow{5}{*}{$6 \mathrm{H}$} & 3 & \multirow{5}{*}{$12+0.064$} & 12.151 & 12.129 & 0.022 & \multirow{4}{*}{$\begin{array}{l}\text { Polymam-T } \\
400 / 315 \mu \mathrm{m}\end{array}$} \\
\hline 2 & & 4.5 & & 12.150 & 12.130 & 0.020 & \\
\hline 3 & & 6 & & 12.137 & 12.128 & 0.009 & \\
\hline 4 & & 7.5 & & 12.153 & 12.121 & 0.032 & \\
\hline 5 & & 7.5 & & 12.144 & 12.120 & 0.024 & $\begin{array}{l}\text { Polymam-T } \\
630 / 400 \mu \mathrm{m}\end{array}$ \\
\hline
\end{tabular}

The outer diameter of the taps decreased on average by $20 \mu \mathrm{m}$ after $3-6$ minutes of MAM and by $25-30 \mu \mathrm{m}$ after 7.5 minutes. It is important to emphasize that the diameter almost did not change between 3 and 6 minutes of machining. This can be explained by the fact that in the first minutes of the process there is an intensive removal of the burrs and rounding of sharp edges on the tops of the teeth. Also during this time the defective layer of material that was 
formed at the grinding stage is removed, stress concentrators are removed, carbides are crushed and the tool surface is strengthened [15]. The internal stresses and the dislocation density at the boundary reaches a critical value and they come to the surface in the form of microcracks and material peeling $[2,16]$ after 6 minutes of machining as a result of shock interaction of quasistable volumes of a magneto-abrasive tool with the tap surface. At this time, the material is removed from the surface, which leads to increase of the radiuses of cutting edges rounding and to decrease in the diameter of the tool. These processes are cyclically repeated after a certain period of time, this process is similar to cascade wear during friction.

The machining conditions of the M10 taps are similar as for the M12 taps, except the grit of the magneto-abrasive powder. The results of measuring the outer diameter of the M10 taps are presented in Table 2.

Table 2

The results of measuring the outer diameter of the M10 taps

\begin{tabular}{|c|c|c|c|c|c|c|c|}
\hline \multirow[b]{2}{*}{ № } & \multirow{2}{*}{$\begin{array}{c}\text { Tap } \\
\text { accuracy }\end{array}$} & \multirow{2}{*}{$\begin{array}{c}\text { Total } \\
\text { machining } \\
\text { time, min }\end{array}$} & \multicolumn{5}{|c|}{ Outer diameter $d, \mathrm{~mm}$} \\
\hline & & & $\begin{array}{c}\text { GOST } \\
16925-93\end{array}$ & $\begin{array}{l}\text { Before } \\
\text { MAM }\end{array}$ & $\begin{array}{l}\text { After } \\
\text { MAM }\end{array}$ & $\Delta d, \mathrm{~mm}$ & MAP \\
\hline 1 & \multirow{5}{*}{$6 \mathrm{H}$} & 3 & \multirow{5}{*}{$10_{+0.050}$} & 10.124 & 10.097 & 0.027 & \multirow{5}{*}{$\begin{array}{c}\text { Polymam- } \\
\text { T 200/ } \\
100 \mu \mathrm{m}\end{array}$} \\
\hline 2 & & 4.5 & & 10.096 & 10.096 & 0.000 & \\
\hline 3 & & 6 & & 10.111 & 10.094 & 0.017 & \\
\hline 4 & & 7 & & 10.147 & 10.126 & 0.021 & \\
\hline 5 & & 7.5 & & 10.125 & 10.097 & 0.028 & \\
\hline
\end{tabular}

After MAM of M10 taps by powder Polymam-T 200/100 $\mu \mathrm{m}$ were obtained similar results as for M12 taps. Sharp diameter decrease by $20 \mu \mathrm{m}$ occurs in the first 2-3 minutes of the process and remains unchanged up to 7 minutes. For M10 taps the cycle of strengthening the surface layer takes longer, since the contact area of the powder particles of the $200 / 100 \mu \mathrm{m}$ grit with the machined surface is less than using the $400 / 315 \mu \mathrm{m}$ grit [16]. A further increase in machining time leads to the removal of a larger allowance and decrease in diameter on the next minute to $25-30 \mu \mathrm{m}$.

Machining conditions of M6 taps: speed of movement along the ring-type working area of the machine $-\mathrm{V}_{\mathrm{B}}=2.5 \mathrm{~m} / \mathrm{s}$, the rotational speed around its own axis $-\mathrm{V}_{\mathrm{O}}=500 \mathrm{rpm}$, value of the magnetic induction in the working area $B=0.2 \mathrm{~T}$, angle $\mathrm{p}=70^{\circ}$. The results of measuring the outer diameter of the M6 taps are presented in Table 3.

For M6 taps, which were machined according to dimensions with other conditions, the results of the measured diameter have the same tendency as the previous ones. The diameter decreased by $15 \mu \mathrm{m}$ in the first 3 minutes of the process and did not change until 5 minutes of machining. 


\section{Table 3}

The results of measuring the outer diameter of the M6 taps

\begin{tabular}{|c|c|c|c|c|c|c|c|}
\hline \multirow[b]{2}{*}{ № } & \multirow{2}{*}{$\begin{array}{c}\text { Tap } \\
\text { accuracy }\end{array}$} & \multirow{2}{*}{$\begin{array}{c}\text { Total } \\
\text { machining } \\
\text { time, min }\end{array}$} & \multicolumn{5}{|c|}{ Outer diameter $d, \mathrm{~mm}$} \\
\hline & & & $\begin{array}{c}\text { GOST } \\
16925-93\end{array}$ & $\begin{array}{l}\text { Before } \\
\text { MAM }\end{array}$ & $\begin{array}{l}\text { After } \\
\text { MAM }\end{array}$ & $\Delta d, \mathrm{~mm}$ & MAP \\
\hline 1 & \multirow{5}{*}{$6 \mathrm{H}$} & 1.5 & \multirow{5}{*}{$6+0.047$} & 6.097 & 6.097 & 0.000 & \multirow{5}{*}{$\begin{array}{c}\text { Polymam- } \\
\text { T 200/ } \\
100 \mu \mathrm{m}\end{array}$} \\
\hline 2 & & 2.5 & & 6.094 & 6.090 & 0.004 & \\
\hline 3 & & 3 & & 6.088 & 6.074 & 0.014 & \\
\hline 4 & & 4 & & 6.092 & 6.076 & 0.016 & \\
\hline 5 & & 4.5 & & 6.091 & 6.090 & 0.001 & \\
\hline
\end{tabular}

Conclusions. It was proved that MAM of taps under correctly selected machining time does not leads to a critical change in diameters, which during operation can lead to discarded parts. It was determined that sharp diameter decrease occurs in the first 3-6 minutes of machining. The reason for this is the removal of burrs from the tops of the teeth, grinding defects and rounding of the cutting edges of the tool. The outer diameter for the M12 and M10 taps for the first 3-6 minutes of MAM decreased on average by $20 \mu \mathrm{m}$, for M6 taps - by $15 \mu \mathrm{m}$. The reduction of diameter is cyclically repeated. This is due to the cyclic change in the physical and mechanical properties of thin surface layers of the tool material and their periodic removal.

\section{References}

1. Kireev G. I. Proektirovanie metchikov i kruglyh plashek: uchebnoe posobie. Ulyanovsk: UlGTU, 2008. 107 p. [In Russian].

2. Maiboroda V. S., Slobodianiuk I. V., Dzhulii D. Yu. Magnitno-abrazivnaya obrabotka detalej slozhnoj formy. Zhitomir: Ruta Publ., 2017. 272 p. [In Russian].

3. Dyubner L. G., Maiboroda V. S., Ivanovskii A. A. Magnitno-abrazivnaya obrabotka koncevogo rezhushchego instrumenta. Vestnik NTUU KPI. Mashinostroenie. 2003. Vol. 44. P. 107-108. [In Russian].

4. Denkena B., Köhler J., Mengesha M. S. Influence of the cutting edge rounding on the chip formation process: Part 1. Investigation of material flow, process forces, and cutting temperature. Prod. Eng. Res. 2012. Vol. 6. P. 329-338. doi:10.1007/s11740-012-0366-x. https://doi.org/10.1007/s11740-012-0366-X

5. Tikal F., Bienemann R., Heckmann L. Schneidkantenpräparation Ziele, Verfahren und Messmethoden. Berichte aus Industrie und Forschung. Kassel, Kassel University Press GmbH, 2009. 193 p.

6. Karpuschewski B., Byelyayev O., Maiboroda V. S. Magneto-Abrasive Machining for the Mechanical Preparation of High-Speed Steel Twist Drills. CIRP Annals. Manufacturing Technology. 2009. № 58. P. 295-298. doi:10.1016/j.cirp.2009.03.046. https://doi.org/10.1016/j.cirp.2009.03.046

7. Cheung F. Y., Zhou Z. F., Geddam A., Li K. Y. Cutting edge preparation using magnetic polishing and its influence on the performance of high-speed steel drills. Journal of Materials Processing Technology. 2008. Vol. 208 (1-3). P. 196-204. https://doi.org/10.1016/j.jmatprotec.2007.12.108

8. Baron Yu. M. Magnitno-abrazivnaya i magnitnaya obrabotka izdelij i rezhushchih instrumentov. Leningrad. Mashinostroenie Publ. 1986. 176 p. [In Russian].

9. Akulovich L. M., Srgeev L. E., Lebedev V. Ya. Osnovy magnitno-abrazivnoj obrabotki metallicheskih poverhnostej. Minsk: BGATU, 2012. 316 p. [In Russian].

10. Homich N. S. Magnitno-abrazivnaya obrabotka izdelij. Minsk: BNTU, 2006. 218 p. [In Russian].

11. Byelyaev O. Erhöhung der Leistungsfähigkiet von HSS Spiralbohrern durch Einsatz der magnetabrasiven Bearbeitung. Dissertation Dr.-Ing. Magdeburg, 2008. 149 p.

12. Keksin A. I. Povyshenie kachestva vnutrennih rezbovyh poverhnostej na osnove predvaritelnogo magnitno-abrazivnogo polirovaniya slozhnoprofilnogo instrumenta: diss. ... kand. tek. nauk. SanktPeterburg, 2008. 149 p. [n Russian] 
13. Homenko V. A., Ikonnikov A. M., Bogdanov A. V. Magnitno-abrazivnaya obrabotka metchikov. Polzunovskij vesnik. 2012. No. 1/1. P. 318-320. [In Russian].

14. Tarhan D. V., Maiboroda V. S., Dzhulii D. Yu. Analiz intensyvnosti mahnitno-abrazyvnoho obroblennia mitchykiv v zalezhnosti vid kinematychnykh parametriv protsesu. Visnyk KrNU imeni M. Ostrohradskoho. 2017. Vol. 106. P. 82-88. [In Ukrainian].

15. Tarhan D. V., Maiboroda V. S. Vplyv mahnitno-abrazyvnoho obroblennia na tverdist ta strukturu materialu mitchykiv iz shvydkorizalnoi stali. Visnyk KhNTU. Inzhenerni nauky. 2017. Vol. 61. P. 119-125. [In Ukrainian].

16. Maiboroda V.S. Osnovy stvorennia i vykorystannia poroshkovoho mahnitno-abrazyvnoho instrumentu dlia finishnoi obrobky fasonnykh poverkhon: diss. ... dokt. tekhn. nauk, Kyiv. 2001. 404 p. [In Ukrainian].

\section{Список використаної літератури}

1. Киреев Г. И. Проектирование метчиков и круглих плашек: учебное пособие. Ульяновск: УлГТУ, 2008. $107 \mathrm{c}$.

2. Майборода В. С., Слободянюк И. В., Джулий Д. Ю. Магнитно-абразивная обработка деталей сложной формы. Житомир: Рута, 2017. 272 с.

3. Дюбнер Л. Г., Майборода В. С., Ивановский А. А. Магнитно-абразивная обработка концевого режущего инструмента. Вестник Национального технического университета Украины «Киевский политехнический институт». Машиностроение. Вып. 44. 2003. С. 107-108.

4. Denkena B., Köhler J., Mengesha M. S. Influence of the cutting edge rounding on the chip formation process: Part 1. Investigation of material flow, process forces, and cutting temperature. Prod. Eng. Res. 2012. Vol. 6. P. 329-338. doi:10.1007/s11740-012-0366-x. https://doi.org/10.1007/s11740-012-0366-X

5. Tikal F., Bienemann R., Heckmann L. Schneidkantenpräparation Ziele, Verfahren und Messmethoden. Berichte aus Industrie und Forschung. Kassel, Kassel University Press GmbH, 2009. 193 p.

6. Karpuschewski B., Byelyayev O., Maiboroda V. S. Magneto-Abrasive Machining for the Mechanical Preparation of High-Speed Steel Twist Drills. CIRP Annals. Manufacturing Technology. 2009. № 58. P. 295-298. doi:10.1016/j.cirp.2009.03.046. https://doi.org/10.1016/j.cirp.2009.03.046

7. Cheung F. Y., Zhou Z. F., Geddam A., Li K. Y. Cutting edge preparation using magnetic polishing and its influence on the performance of high-speed steel drills. Journal of Materials Processing Technology. 2008. Vol. 208 (1-3). P. 196-204. https://doi.org/10.1016/j.jmatprotec.2007.12.108

8. Барон Ю. М. Магнитно-абразивная и магнитная обработка изделий и режущих инструментов. Ленинград: Машиностроение, 1986. 176 с.

9. Акулович Л. М., Сергеев Л. Е, Лебедев В. Я. Основы магнитно-абразивной обработки металлических поверхностей. Минск: БГАТУ, 2012. 316 с.

10. Хомич Н. С. Магнитно-абразивная обработка изделий. Минск: БНТУ, 2006. 218 с.

11. Byelyaev O. Erhöhung der Leistungsfähigkiet von HSS Spiralbohrern durch Einsatz der magnetabrasiven Bearbeitung. Dissertation Dr.-Ing. Magdeburg, 2008. 149 p.

12. Кексин А. И. Повышение качества внутренних резьбовых поверхностей на основе предварительного магнитно-абразивного полирования сложнопрофильного инструмента: дис. ... канд. техн. наук. Санкт-Петербург, 2017. 200 с.

13. Хоменко В. А., Иконников А. М., Богданов А. В. Магнитно-абразивная обработка метчиков. Ползуновский весник. 2012. № 1/1. С. 318-320.

14. Тарган Д. В., Майборода В. С., Джулій Д. Ю. Аналіз інтенсивності магнітно-абразивного оброблення мітчиків в залежності від кінематичних параметрів процесу. Вісник КрНУ імені Михайла Остроградського. 2017. Вип. № 5 (106). С. 82-88.

15. Тарган Д. В., Майборода В. С. Вплив магнітно-абразивного оброблення на твердість та структуру матеріалу мітчиків із швидкорізальної сталі. Вісник ХНТУ. Інженерні науки. 2017. Вип. № 2 (61). C. 119-125.

16. Майборода В. С. Основи створення і використання порошкового магнітно-абразивного інструменту для фінішної обробки фасонних поверхонь: дис. ... докт. техн. наук. Київ, 2001. 404 с. 
УДК 621.923

\title{
ВПЛИВ ТРИВАЛОСТІ МАГНІТНО-АБРАЗИВНОГО ОБРОБЛЕННЯ НА ТОЧНІСТЬ МІТЧИКІВ ІЗ ШВИДКОРІЗАЛЬНОЇ СТАЛІ
}

\author{
Віктор Майборода ${ }^{1}$; Дмитро Тарган ${ }^{1}$; Олексій Бєляєв ${ }^{2}$; \\ Дмитро Джулій ${ }^{1}$
}

\author{
${ }^{1}$ Національний технічний університет Украӥни «Київський політехнічний \\ інститут імені Ігоря Сікорського», Київ, Украӥна \\ ${ }_{2}^{2 Z O M}$ Oberflächenbearbeitung Gmb», Магдебург, Німеччина
}

\begin{abstract}
Резюме. Представлено результати дослідження впливу тривалості магнітно-абразивного оброблення на точність мітчиків різних діаметрів, виготовлених із швидкорізальної сталі. Дослідження проводили на мітчиках із швидкорізальної сталі P6M5: M12x1,75-6H марки Walter Prototyp PARADUR, M10x1-6H марки Walter Prototyp PARADUR, M6x0,75-6H марки Narex. Проконтрольовано зовнішній діаметр мітчиків до та після МАО. Вимірювання точності проведено на установці для розмірного налаштування та вимірювання різальних інструментів Venturion 450/6 ("ZOM Oberflächenbearbeitung $G m b H »$, Магдебург, Німеччина). Установка обладнана високоточним шпинделем, щяо дозволяє проводити вимірювання діаметра з точністю 0,002 мм. Магнітно-абразивне оброблення мітчиків не призводить до критичної зміни діаметрів, щуо в процесі експлуатації може призвести до браку деталей. Після 3-6 хв МАО зовнішній діаметр мітчиків М12 та М10 зменшився в середньому на 20 мкм, Мб - на 15 мкм. Важливо, щзо діаметр майже не змінився між 3 та 6 хв оброблення. Це можна пояснити тим, щзо в периі хвилини проиесу відбувається інтенсивне видалення рубчиків та округлення гострих кромок на вериинах зубиів. Також за ией час видаляється дефектний шар матеріалу, щзо сформувався на етапі шліфування, знімаються концентратори напружень, відбувається подрібнення карбідів та зміцнення поверхні інструменту. Після 6 хв оброблення, в результаті ударної взаємодії квазістабільних об'ємів магнітноабразивного інструменту з поверхнею мітчика, внутрішні напруження та щільність дислокацій на границі досягає критичного значення й вони виходять на поверхню у вигляді мікротріщин та відшарування матеріалу. В ией момент відбувається видалення матеріалу з поверхні, шзо призводить до збільшення радіусів округлення різальних кромок та зменшення діаметра інструменту. Цей процес ичиклічно повторюється, що пов'язано з циклічною зміною фізико-механічних властивостей тонких поверхневих шарів матеріалу інструменту та їх періодичним видаленням.
\end{abstract}

Ключові слова: мітчик, точність, магнітно-абразивне оброблення. 